\title{
Risk analysis of climate change on coffee nematodes and leaf miner in Brazil
}

\author{
Raquel Ghini(1), Emília Hamada(1), Mário José Pedro Júnior(2), José Antonio Marengo(3) \\ and Renata Ribeiro do Valle Gonçalves ${ }^{(4)}$
}

\begin{abstract}
(1)Embrapa Meio Ambiente, Caixa Postal 69, CEP 13820-000 Jaguariúna, SP, Brazil. E-mail: raquel@cnpma.embrapa.br, emilia@cnpma.embrapa.br (2)Instituto Agronômico, Caixa Postal 28, CEP 13001-970 Campinas, SP, Brazil. E-mail: mpedro@iac.sp.gov.br (3)Centro de Previsão de Tempo e Estudos Climáticos, Rodovia Presidente Dutra, Km 40, CEP 12630-000 Cachoeira Paulista, SP, Brazil. E-mail: marengo@cptec.inpe.br (4)Universidade Estadual de Campinas, Faculdade de Engenharia Agrícola, Caixa Postal 6011, CEP 13083-875 Campinas, SP, Brazil.

E-mail: renaribeiro@yahoo.com.br
\end{abstract}

\begin{abstract}
The objective of this work was to assess the potential impact of climate change on the spatial distribution of coffee nematodes (races of Meloidogyne incognita) and leaf miner (Leucoptera coffeella), using a Geographic Information System. Assessment of the impacts of climate change on pest infestations and disease epidemics in crops is needed as a basis for revising management practices to minimize crop losses as climatic conditions shift. Future scenarios focused on the decades of the 2020's, 2050's, and 2080's (scenarios A2 and B2) were obtained from five General Circulation Models available on Data Distribution Centre from Intergovernmental Panel on Climate Change. Geographic distribution maps were prepared using models to predict the number of generations of the nematodes and leaf miner. Maps obtained in scenario A2 allowed prediction of an increased infestation of the nematode and of the pest, due to greater number of generations per month, than occurred under the climatological normal from 1961-1990. The number of generations also increased in the B2 scenario, but was lower than in the A2 scenario for both organisms.
\end{abstract}

Index terms: Coffea arabica, Leucoptera coffeella, Meloidogyne incognita, global warming, pest zoning.

\section{Análise de risco da mudança climática sobre nematóides e o bicho-mineiro do cafeeiro no Brasil}

\begin{abstract}
Resumo - O objetivo deste trabalho foi avaliar os impactos potenciais da mudança climática sobre a distribuição espacial de nematóides (raças de Meloidogyne incognita) e do bicho-mineiro (Leucoptera coffeella) da cultura de café, com uso de Sistema de Informações Geográficas. O conhecimento dos impactos da mudança climática na ocorrência de pragas e doenças é de grande importância para o setor agrícola, pois permite a elaboração de estratégias para minimizar prejuízos futuros. Cenários futuros centrados nas décadas de 2020, 2050 e 2080 (cenários A2 e B2), foram obtidos a partir de cinco Modelos Climáticos Globais, disponibilizados pelo Centro de Distribuição de Dados do Painel Intergovernamental sobre Mudança do Clima. Por meio de modelos para previsão do número de gerações anuais do nematóide e do bicho-mineiro, foram elaborados mapas de distribuição geográfica. Os mapas obtidos no cenário A2 permitem verificar que poderá haver aumento na infestação, tanto do nematóide quanto da praga, pelo maior número de gerações por mês, quando se compara com a normal climatológica de 1961-1990. No cenário B2, o número de gerações também foi maior que no cenário atual, porém nota-se que é inferior ao observando no cenário A2.
\end{abstract}

Termos para indexação: Coffea arabica, Leucoptera coffeella, Meloidogyne incognita, aquecimento global, zoneamento de pragas.

\section{Introduction}

The Fourth Assessment Report of the Intergovernmental Panel on Climate Change (IPCC, 2007) indicates that there is a very high confidence that anthropogenic greenhouse gas emissions have caused global warming. This warming causes greater atmospheric dynamics, accelerating the hydrologic and energy cycles in the atmosphere, which consequently can affect the frequency and intensity of extreme climatic 
events. Changes in these processes can augment ecosystem instability and accelerate natural species extinction rates.

Several models have been developed to project changes in climate and in processes influenced by greenhouse gas increases. IPCC's Data Distribution Center (DDC) offers future climatic scenarios projected using different General Circulation Models (GCM). Such scenarios are grouped into four families (A1, B1, A2, and B2). These families consider different projections and regional differences in greenhouse gas emissions, aspects of economic growth and population growth, levels of concern about the environment, changes in technology, energy use and land-use (IPCC, 2006).

Climate changes may alter the current scenario of pests and diseases in Brazilian agriculture. Modifications in the relative importance of these problems might occur in the near future. The resulting economic, social, and environmental impacts could be positive, negative, or neutral, since the climate change may decrease, increase, or have no effect on the different pest problems that occur in each region. For this reason, an analysis of the possible impacts of global climate change on plant pests and diseases is essential for mitigating approaches, in order to minimize potential loss (Chakraborty, 2005; Ghini, 2005).

According to Randig et al. (2004), Meloidogyne incognita is one of the most important species of nematode that attacks coffee (Coffea arabica) in Brazil. Root disease caused by the pathogen is more serious in sandy soil regions of the states of São Paulo, Paraná, and southern Minas Gerais. Symptoms include root necrosis, which reduces absorption of water and nutrients by the plant and contributes to decreased yield and even plant death. To estimate the number of generations of the nematode in different regions of the country, Jaehn (1991) determined thermal constants for races 1,2, and 4 of M. incognita. Thermal constant is the amount of heat, or total effective temperatures, that each species requires to complete its life cycle, and is calculated subtracting the lower thermal threshold from the average daily temperature; the result is multiplied by the duration of the cycle (Salama et al., 2002). Temperature requirements of races 1 and 2 were similar, but race 4 required more days to complete its life cycle and so has a higher thermal requirement for completing its life cycle.

The leaf miner Leucoptera coffeella, considered the most important pest of coffee, occurs in all producing regions in Brazil. Until 1970, it was considered a problem only during the dry period of the year. However, recently, the pest has occurred during the dry and rainy seasons, causing damage in the order of $37 \%$ in some regions of São Paulo (Gallo et al., 2002). Considering that temperature is one of the main factors governing this pest's population dynamics, Parra (1985) developed a method for predicting the number of annual generations of the coffee leaf miner in the State of São Paulo, based on the thermal constants for the different stages of its biological cycle.

This work aimed to assess the potential impact of climate change on the spatial distribution of coffee nematodes (races of Meloidogyne incognita) and leaf miner (Leucoptera coffeella), using a Geographic Information System (GIS), comparing the climatological normal from 1961-1990 with the decades of the 2020's, 2050's, and 2080's, using scenarios A2 and B2 (IPCC, 2006).

\section{Materials and Methods}

Idrisi 32, a GIS software, was used to obtain the maps. The GIS input information was the mean monthly temperatures of climatological normal from 1961-1990 (standard reference) and future climates for Brazil, obtained from IPCC (2006). The future scenarios A2 and B2 were used to project for the decades of the 2020's (between 2010 and 2039), 2050's (between 2040 and 2069), and 2080's (between 2070 and 2099) from five GCM, which are: ECHAM4 from Max Planck Institute für Meteorologie, Germany; HadCM3 from Hadley Centre for Climate Prediction and Research, UK; CGCM2 from Canadian Centre for Climate Modelling and Analysis, Canada; CSIRO-Mk2 from Australian's Commonwealth Scientific and Industrial Research Organization, Australia; CCSR/NIES from Center for Climate System Research, National Institute for Environmental Studies, Japan.

A2 scenario describes a very heterogeneous world. The underlying theme is self-reliance and preservation of local identities. Fertility patterns across regions converge very slowly, which results in continuously increasing global population. Economic development is primarily regionally oriented and per capita economic growth as well as technological changes are more fragmented and slower than in other storylines. The B2 scenario describes a world in which the emphasis is on 
local solutions to economic, social, and environmental sustainability. It is a world with continuously increasing global population at a rate lower than A2, intermediate levels of economic development, and less rapid and more diverse technological change than in the $\mathrm{B} 1$ and $\mathrm{A} 1$ storylines. While the B2 scenario is also oriented toward environmental protection and social equity, it focuses on local and regional levels (IPCC, 2001).

Mean air temperature information for the future climate was made available in grid format, with different spatial resolutions (ECHAM4: $2.8125 \times 2.8125^{\circ}$, HadCM3: $3.75 \times 2.5^{\circ}$, CGCM2: $3.75 \times 3.75^{\circ}$, CSIROMk2b: $5.625 \times 3.214^{\circ}$, and CCSR/NIES: $5.625 \times 5.625^{\circ}$ ). These data were later interpolated by the Inverse Square Distance to a power method, maintaining the same spatial resolution of $0.5 \times 0.5^{\circ}$, latitude and longitude, used for the normal climate. The area corresponding to the main coffee producing regions was selected from the georeferenced data and a mask delimiting the Brazilian states (Bahia, Espírito Santo, Goiás, Mato Grosso, Mato Grosso do Sul, Minas Gerais, Paraná, Rio de Janeiro, Rondônia, and São Paulo) was overlaid onto the maps.

The mean monthly air temperature for the future scenario was obtained by the average from the five models using the GIS software spatial analysis tools (arithmetic operation). Mean soil temperature was estimated according to the equations obtained by Alfonsi \& Sentelhas (1996), at $5 \mathrm{~cm}$ [(soil temperature at $5 \mathrm{~cm}$ depth $)=-5.031+1.40($ air temperature $)]$ and $40 \mathrm{~cm}$ depth [(soil temperature at $40 \mathrm{~cm}$ depth $)=-0.646+$ 1.18(air temperature)]. Geographic distribution maps of the probable numbers of generations for races 1,2, and 4 of $M$. incognita for the current and future climates were obtained using the thermal constant model of Jaehn (1991). For races 1 and 2 of $M$. incognita, thermal requirements value ( $\mathrm{K}$, in degree-days) was 557 [average of race $1(\mathrm{~K}=534)$ and race $2(\mathrm{~K}=580)$ ]; for race $4, K=718$. Base temperature assumed for all races was $10^{\circ} \mathrm{C}$ (Jaehn, 1991).

Geographic distribution maps of the probable numbers of generations of coffee leaf miner were obtained using the thermal requirements $\mathrm{K}=304$, and a base temperature of $11.4^{\circ} \mathrm{C}$ (Parra, 1985).

\section{Results and Discussion}

The geographic distribution maps obtained for the probable number of generations of $M$. incognita races 1 , 2 (Figure 1) and 4 (Figure 2), and Leucoptera coffeella
(Figure 3) under the future scenarios demonstrated a tendency of increase in infestation when these are compared with the climatological normal from 19611990. Thus, global warming may result in an intensification of the importance of these problems.

For the 2020's and 2050's, there is little difference between the probable number of annual generations obtained under the A2 and B2 scenarios. For example, in 2020, the area with 9 to 12 annual generations of races 1 and 2 of $M$. incognita was $41 \%$ of the total area studied under scenario A2 and 40\% under B2; with 12 to 15 generations, 59 and $60 \%$, respectively (Figure 1). However, differences for the 2080's were pronounced, i.e., there was a larger area with a higher number of generations under the A2 scenario than under B2. This result is due to the cumulative effect of greenhouse gas emissions during a longer time period, until the year 2080, under the assumption that measures would not be adopted to minimize them.

Generally, under scenario B2, the number of generations of the nematode and the coffee leaf miner increased but the increase was lower than that obtained under the A2 scenario (Figures 1,2 and 3). These findings result from the characteristics of the predicted scenario families, i.e., scenario B2 is less pessimistic than scenario A2, based on the assumption of lower greenhouse gas emissions, with smaller population growth and more gradual changes in the economic structure.

Parra's model (Parra, 1985), developed for the State of São Paulo, showed satisfactory results when applied to describe the number of coffee leaf miner generations under the climatological normal from 1961-1990 for the entire country. It can be noted that there is a pest development peak in October (Figure 3), which agrees with the population fluctuation data presented by Reis \& Souza (1998) and by Tuelher et al. (2003). This tendency for greater increase in development of the pest during that month was also observed in the future scenarios.

The main damage caused by the leaf miner in coffee plantations is a reduction in photosynthetic capacity because of leaf destruction (Gallo et al., 2002). Decreased productivity occurs as incidence of the pest increases at different developmental stages of the crop, if supplementary control measures are not taken. The main control method is by chemical pesticides which, when applied indiscriminately, may cause biological imbalances, favoring outbreaks of mites (Gallo et al., 2002). 


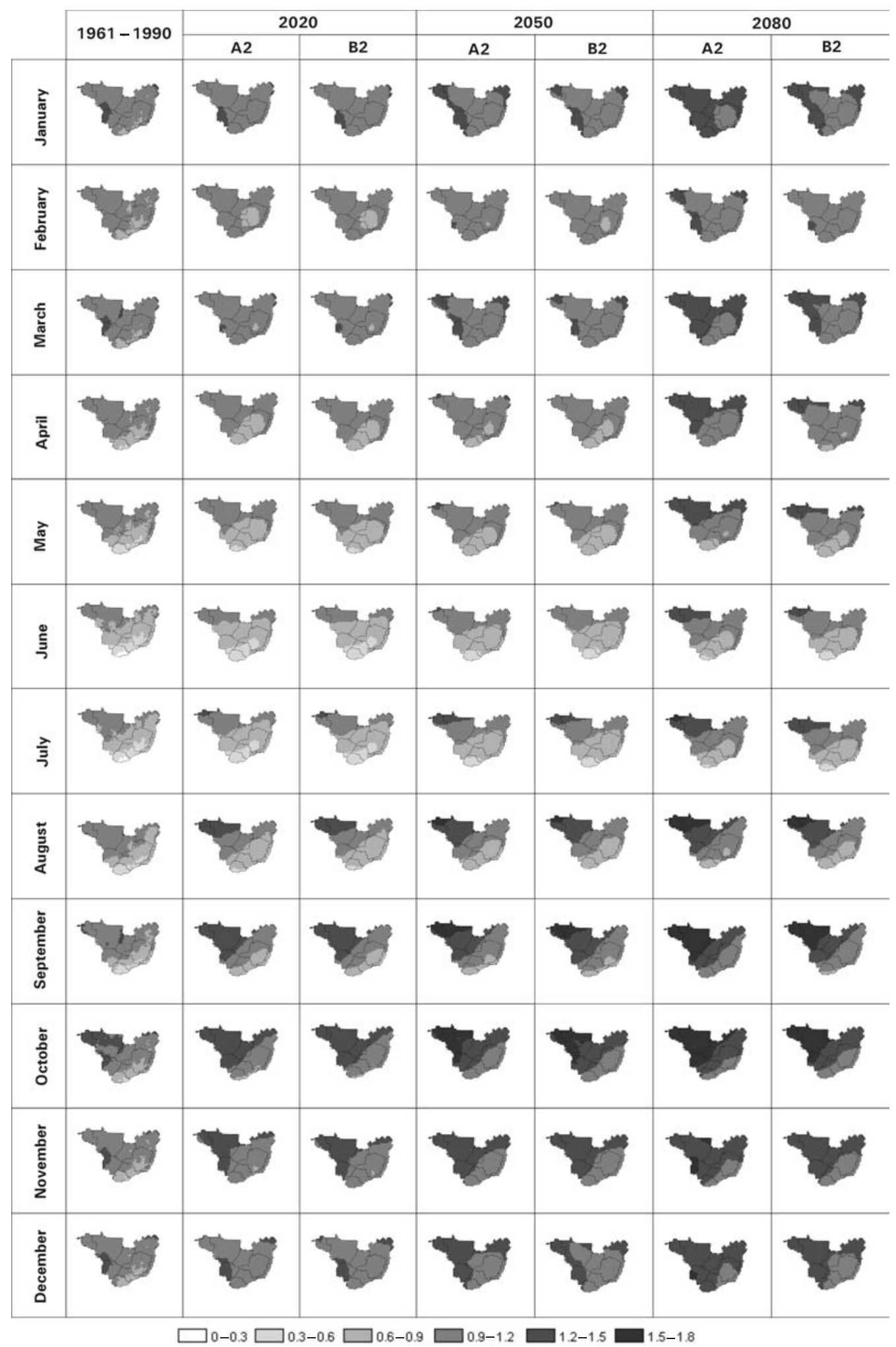

Figure 1. Maps of probable number of generations of Meloidogyne incognita races 1 and 2 on coffee plants, from January to December, for the climatological normal from 1961-1990 and future climates $(2020,2050$, and 2080) in scenarios A2 and B2. 


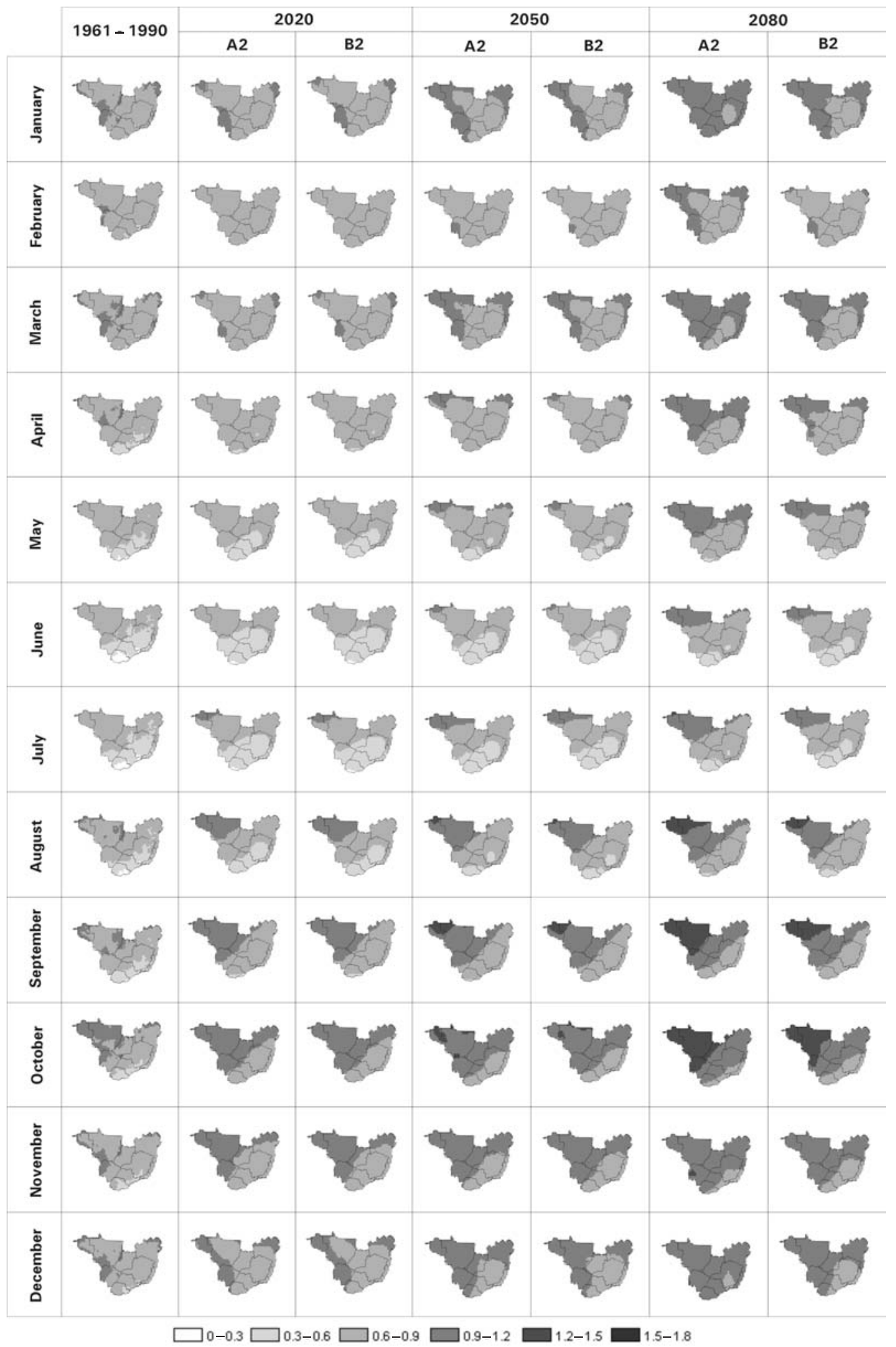

Figure 2. Maps of probable number of generations of Meloidogyne incognita race 4 on coffee plants, from January to December, for the climatological normal from 1961-1990 and future climates (2020, 2050, and 2080) in scenarios A2 and B2. 


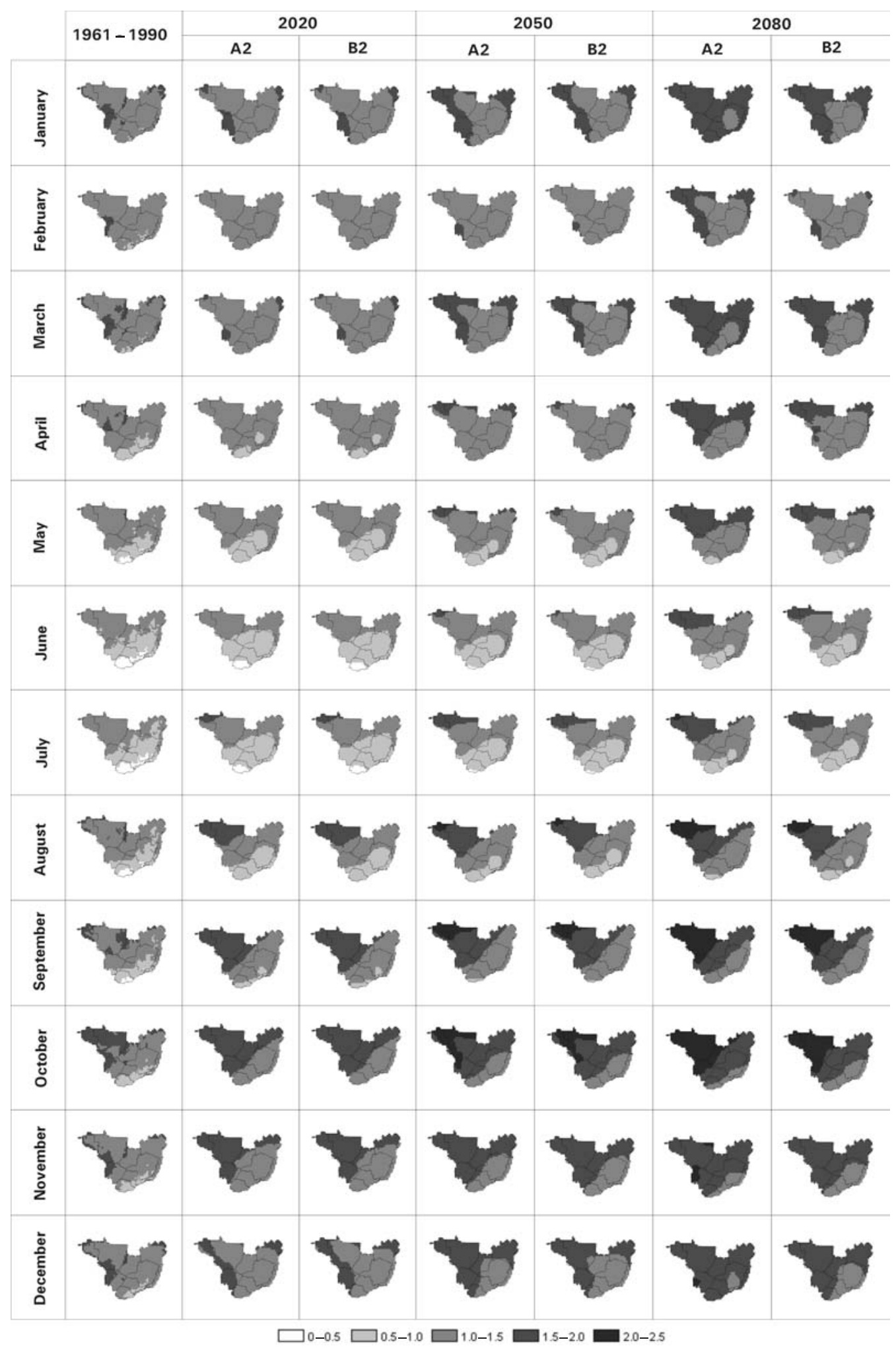

Figure 3. Maps of probable number of generations of coffee leaf miner (Leucoptera coffeella) on coffee plants, from January to December, for the climatological normal from 1961-1990 and future climates (2020, 2050, and 2080) in scenarios A2 and B2. 
A similar prediction was obtained for the races of M. incognita (Figures 1 and 2), i.e., that the number of generations per year will increase in future scenarios. Races 1 and 2 showed more intense development than race 4, as can also be observed in the 1961-1990 climatological normal. Due to the fact that this is a soil-borne plant pathogen, the most important control method consists in the adoption of preventive measures, avoiding the introduction of the nematode in the area. However, after its establishment, a control strategy must be implemented, because infestation seriously compromises productivity.

Climate change will certainly affect the development of the coffee crop, as discussed by Assad et al. (2004). According to these authors, areas that are unsuitable for coffee growing will significantly increase until the end of the century, displacing cultivated areas towards the South and higher regions, due to their milder climate. The study considered that the ideal condition for economic development of the crop is mean annual temperatures between 18 and $23^{\circ} \mathrm{C}$.

Other environmental factors, in addition to those studied, can also change the distribution of the potential pressure by the nematode and the pest in different regions of the country, and warrant more in-depth study. The effect of precipitation and the complex interaction of high temperatures and other variables on the leaf miner were not evaluated. High temperatures can induce the nematode to migrate deeper into the soil, where the conditions are different from those near the surface and can alter the development and population dynamics of the pest. In some scenarios where increased temperatures are associated with reduced rainfall, the thresholds for nematode damage will also be reduced. As long as the conditions do not reduce the infectivity of nematodes by reducing their mobility, nematodes are likely to be much more damaging.

In most papers, authors simplify the methodology of analysis by assuming a constant temperature or precipitation value that is added to current mean values, regardless of season of the year or geographic region studied. The GCM made available by the IPCC are more adequate, since seasonal and spatial alterations are predicted. Only few studies used GCM to evaluate the impacts on pests and diseases (Bergot et al., 2004; Salinari et al., 2006; Ghini et al., 2007). The models, however, have a number of limitations. The development of pests and plant diseases may not present a linear response to the climatic factor under study. The potential for adaptation of plants and pests is another complicating factor that is often ignored in models. The low temporal and spatial resolution of GCM outputs makes it difficult to link predicted climate scenarios to crop or pest development models, which require daily or even hourly information (Scherm \& van Bruggen, 1994; Garrett et al., 2006). However, despite the limitations of the results obtained, this method provides a useful instrument to study the impacts of climate change.

\section{Conclusions}

1. The infestation of Meloidogyne incognita races 1, 2 and 4, and Leucoptera coffeella on coffee under the future scenarios will increase when compared with the climatological normal from 1961-1990.

2. The number of generations of nematodes and coffee leaf miner will increase in both scenarios (A2 and B2), but for B2, it will be lower than in the A2 scenario.

\section{Acknowledgements}

To Daniel Marcello Braida and Danilla Alves Pereira, for collaboration during the preparation of maps; to Conselho Nacional de Desenvolvimento Científico e Tecnológico, for grant and scholarship to authors; to Embrapa and Probio Project, for financial support.

\section{References}

ALFONSI, R.R.; SENTELHAS, P.C. Estimativa da temperatura do solo através da temperatura do ar em abrigo meteorológico. Revista Brasileira de Agrometeorologia, v.4, p.57-61, 1996.

ASSAD, E.D.; PINTO, H.S.; ZULLO JÚNIOR, J.; ÁVILA, A.M.H. Impacto das mudanças climáticas no zoneamento agroclimático do café no Brasil. Pesquisa Agropecuária Brasileira, v.39, p.10571064, 2004

BERGOT, M.; CLOPPET, E.; PÉRARNAUD, V.; DÉQUÉ, M.; MARÇAIS, B.; DESPREZ-LOUSTAU, M.L. Simulation of potential range expansion of oak disease caused by Phytophthora cinnamomi under climate change. Global Change Biology, v.10, p.1539-1552, 2004.

CHAKRABORTY, S. Potential impact of climate change on plantpathogen interactions. Australasian Plant Pathology, v.34, p.443448, 2005.

GALLO, D.; NAKANO, O.; SILVEIRA NETO, S.; CARVALHO, R.P.L.; BAPTISTA, G.C.; BERTI FILHO, E.; PARRA, J.R.P.; ZUCCHI, R.A.; ALVES, S.B.; VENDRAMIM, J.D.; MARCHINI, L.C.; LOPES, J.R.S.; OMOTO, C. Entomologia agrícola. Piracicaba: Fealq, 2002. 920p. 
GARRETT, K.A.; DENDY, S.P.; FRANK, E.E.; ROUSE, M.N.; TRAVERS, S.E. Climate change effects on plant disease: genomes to ecosystems. Annual Review of Phytopathology, v.44, p.489-509, 2006.

GHINI, R. Mudanças climáticas globais e doenças de plantas. Jaguariúna: Embrapa Meio Ambiente, 2005, 104p.

GHINI, R.; HAMADA, E.; GONÇALVES, R.R.V.; GASPAROTTO, L.; PEREIRA, J.C.R. Análise de risco das mudanças climáticas globais sobre a sigatoka-negra da bananeira no Brasil. Fitopatologia Brasileira, v.32, p.197-204, 2007.

IPCC. Climate Change 2001: synthesis report. Cambridge: Cambridge University Press, 2001. 398p.

IPCC. Climate Change 2007: the physical science basis. Available at: http://ipcc-wg1.ucar.edu/wg1/wg1-report.html. Accessed on: 15 Aug. 2007.

IPCC. IPCC SRES climate scenarios: the IPCC data distribution centre. Available at: http://www.ipcc-data.org/sres/gcm_data.html. Accessed on: 26 Apr. 2006.

JAEHN, A. Determinação da constante térmica das raças 1, 2 e 4 de Meloidogyne incognita em cafeeiro. Nematologia Brasileira, v.15, p.135-142, 1991.

PARRA, J.R.P. Biologia comparada de Perileucoptera coffeella (Guérin-Mèneville, 1842) (Lepidoptera, Lyonetiidae) visando ao seu zoneamento ecológico no Estado de São Paulo. Revista Brasileira de Entomologia, v.29, p.45-76, 1985.

RANDIG, O.; CARNEIRO, R.M.D.G.; CASTAGNONE-SERENO, P. Identificação das principais espécies de Meloidogyne parasitas do cafeeiro no Brasil com marcadores SCAR-café em Multiplex-PCR. Nematologia Brasileira, v.28, p.1-10, 2004.

REIS, P.R.; SOUZA, J.C. Manejo integrado das pragas do cafeeiro em Minas Gerais. Informe Agropecuário, v.19, p.17-25, 1998.

SALAMA, H.S.; HAMDY, M.K.; EL-DIN, M.M. The thermal constant for timing the emergence of the red palm weevil, Rhynchophorus ferrugineus (Oliv.) (Coleoptera, Curculionidae). Journal of Pest Science, v.75, p.26-29, 2002.

SALINARI, F.; GIOSUÈ, S.; TUBIELLO, F.N.; RETTORI, A.; ROSSI, V.; SPANNA, F.; ROSENZWEIG, C.; GULLINO, M.L. Downy mildew (Plasmopara viticola) epidemics on grapevine under climate change. Global Change Biology, v.12, p.1299-1307, 2006.

SCHERM, H.; VAN BRUGGEN, A.H.C. Global warming and nonlinear growth: how important are changes in average temperature? Phytopathology, v.84, p.1380-1384, 1994.

TUELHER, E.S.; OLIVEIRA, E.E.; GUEDES, R.N.C.; MAGALHÃES, L.C. Ocorrência de bicho-mineiro do cafeeiro (Leucoptera coffeella) influenciada pelo período estacional e pela altitude. Acta Scientiarum: Agronomy, v.25, p.119-124, 2003.

Received on September 5, 2007 and accepted on January 31, 2008 